\section{Bare psykisk}

Jeg bestemmer meg for å løfte armen. Den beveger seg. Så enkelt. Likevel rommer dette hele gåten - for hvordan kan en tilsynelatende immateriell vilje manifestere seg i en materiell handling? Den materielle virkelighet synes for de fleste av oss å være intuitivt vesensforskjellig fra den mentale, som bare er tilgjengelig gjennom vår egen subjektive bevissthet. En slik vesensforskjellighet står i motsetning til eksemplet med armen, som jo viser at det er en kontinuerlig og sømløs interaksjon mellom disse tilsynelatende to verdener (1), som i daglig væren likevel ikke kan skilles fra hverandre.

I vår kultur er det som oftest René Descartes (1596-1650) som får «skylden» for dualismen. Men hvorvidt han var så dualistisk som vi skal ha det til, er fortsatt omdiskutert (2). Og tenkere og praktikere både før og etter ham har vært skeptiske til todelingen av mennesket. Aristoteles (384-322 f.kr.) avviste skillet mellom legeme og sjel (3). Nevrologiens grunnlegger, Jean Martin Charcot (1825-1893), var sikker på at årsaken til hysteri, selve sinnbildet på den «psykiske» lidelse, lå i hjernen (4). Og Sigmund Freud (1856-1939) insisterte på å kalle psykoanalysen for en «biologisk psykologi» (4).

Ettertiden har gitt dem alle rett. Nevrobiologisk sett er det all mulig grunn til å lukke det kunstige skillet mellom kroppen og dens beboer. De to er ett og det samme. Eksemplet er våre følelser, som i moderne nevrobiologisk forståelse anses som representasjoner av kroppens fysiologiske tilstand, oppstått for å fasilitere individets læring av hvilke kroppstilstander som bør oppsøkes eller unngås (5). Følelsenes nevrobiologiske substrat ligger hovedsakelig i de fylogenetisk eldre delene av hjernen. Det er derfor postulert at følelser som nevrobiologisk fenomen la grunnlaget for utviklingen av høyere nivåer av kognisjon og bevissthet (5). Innsikten i følelsenes nevrobiologi er slik sett i ferd med å gi en biologisk forståelse av de tilsynelatende immaterielle prosesser i vår hjerne. Og tenker vi oss om, er dette godt overensstemmende med våre daglige erfaringer. For følelser er kroppslige i sin natur. Vi rødmer av skam, får hjertebank av glede, åndenød av redsel og tårer av fortvilelse.

Den integrerte forståelsen av menneskehjernen gir også innsikt i de ytre livsbetingelsers betydning for helse og for hvordan både «psykiske» og «fysiske» erfaringer i videste forstand endrer individets egenskaper på molekylært nivå. Epigenetiske modifikasjoner er resultater av miljøpåvirkning og endrer det genetiske uttrykket (6). Overveldende mengder nevrobiologisk forskning har vist hvordan læring endrer menneskehjernen både fysiologisk og anatomisk. Alle erfaringer setter biologiske spor, uavhengig av om de er «fysiske» eller «psykiske». Andre oppdagelser, som hjernens speilnevronsystemer, har åpnet for ny forståelse av de nevrofysiologiske prosessene bak sosial interaksjon. Både fysiologiske og anatomiske endringer i hjernen kan påvises etter psykoterapeutisk intervensjon og ligner effektene av farmakoterapi på tilsvarende sykdommer (7). Forskning på effektene av så ulike terapiformer som dyp hjernestimulering, kognitiv atferdsterapi og nevrofeedback har vist hvordan både kirurgisk, medisinsk og psykologisk behandling gir målbare nevroanatomiske og -fysiologiske endringer i hjernen ved «psykiske» lidelser (8).

Like fullt består dualismen, først og fremst i de folkelige forestillinger, som eksemplifisert i debattene om kronisk utmattelsessyndrom/myalgisk encefalopati (9), men kanskje mer overraskende også langt inn i nevrovitenskapelige tekster (10). Forbausende ofte er den dualistiske sykdomsoppfattelsen koblet til hierarkiske forestillinger, der sykdommer som oppfattes som «fysiske» synes å ha høyere prestisje enn sykdommer som oppfattes som «psykiske».

Det er sannsynlig at hjernens kompleksitet setter begrensninger på vår forståelse av den. Om fysikkens lover gjelder for alle aspekter av hjernen, kan den teoretisk sett kartlegges fullstendig. Men noen av hjernens selvrefererende egenskaper kan sette grenser for hvor langt slik kartlegging kan nå (11). Eksempelvis kan det hevdes at det å postulere et fenomen som «fri vilje» forutsetter at en fullstendig biofysisk forklaringsmodell for hjernen ikke er mulig å oppnå. For i et fullt ut kartlagt biofysisk system vil man teoretisk sett eksakt kunne beregne responsen på enhver stimulus og dermed umuliggjøre noe slikt som «fri vilje» (11). Enkelt sagt: Om hjernen var så enkel at vi forsto den, ville vi være så enkle at vi ikke forsto den (12).

Den menneskelige hjerne er den mest komplekse struktur vi kjenner til. Det burde gi oss ydmykhet til å innse at vi aldri kan forstå den fullt ut. Men det burde også gi oss ydmykhet for at vår intuitive forståelse av den kan være forrædersk feil. Den intuitive tro på skillet mellom et psykisk og et fysisk selv står i veien for en integrert forståelse av oss som hele mennesker. Mennesket er ikke et sinn og en kropp, men begge deler uatskillelig og på én gang. Ingenting er «bare psykisk».

\section{Litteratur}

1. Forstmann M, Burgmer P. Adults are intuitive mind-body dualists. J Exp Psychol Gen 2015; 144: 222-35

2. Kirkebøen G. Descartes' embodied psychology: Descartes' or Damasio's error? $J$ Hist Neurosci 2001; 10: 173-91.

3. Santoro G. Wood MD, Merlo L et al. The anatomic location of the soul from the heart, through the brain, to the whole body, and beyond: a journey through Western history, science, and philosophy. Neurosurgery 2009; 65: 633-43.

4. Hustvedt S. Philosophy matters in brain matters. Seizure 2013; 22: 169-73.

5. Damasio A, Carvalho GB. The nature of feelings: evolutionary and neurobiological origins. Nat Rev Neurosci 2013; 14: 143-52.

6. Getz L, Kirkengen AL, Ulvestad E. Menneskets biologi - mettet med erfaring. Tidsskr Nor Legeforen 2011; 131: 683-7.

7. Etkin A, Pittenger C, Polan HJ et al. Toward a neurobiology of psychotherapy: basic science and clinical applications. J Neuropsychiatry Clin Neurosci 2005; 17: $145-58$.

8. Glannon W. Neuromodulation and the mind-brain relation. Front Integr Nuerosci 2015; 9: 22.

9. Wyller VB, Reme SE, Mollnes TE. Kronisk utmattelsessyndrom/myalgisk encefalopati - sykdomsmekanismer, diagnostikk og behandling. Tidsskr Nor Legeforen 2015: 135: 2172-5.

10. Mudrik L, Maoz U. «Me \& my brain»: exposing neuroscience's closet dualism. $J$ Cogn Neurosci 2015; 27: 211-21.

11. Gierer A. Brain, mind and limitations of a scientific theory of human consciousness. BioEssays 2008: 30: 499-505

12. Barker D. Lyall Watson. The Guardian 23.5.2008. www.theguardian.com/ science/2008/jul/23/pressandpublishing (9.12.2015). 